\title{
Optimizing Effort to Quell The Crime of Violence in The Perspective of A Criminal Policy Approach
}

\author{
Imam Ramadhani \\ Trisakti University, Jakarta, Indonesia \\ Email: Imamrahmaddani92@gmail.com
}

\section{ARTICLE INFO}

Received: 05-01-2022

Revision: 13-01-2022

Received : 18-01-2022

\section{Keywords:}

Crime;

Theft;

Violence

\section{ABSTRACT}

There are three objectives to be achieved in this research, namely; the first examines and analyzes efforts to overcome the crime of theft with violence in the perspective of a criminal policy approach, the second examines and analyzes the factors that encourage and cause criminal acts of theft with violence in Indonesia. Violence is going well in Indonesia. With Problem Formulation 1. How are the efforts to tackle the crime of theft with violence in the perspective of a criminal policy approach? 2. What factors encourage criminal acts of theft with violence to occur in Indonesia?. 3. How does the ideal policy in efforts to overcome the crime of theft with violence work well in Indonesia? This study uses a qualitative method with descriptive-analytical research specifications that describe the legislation. The stages of the research were carried out in two stages: library research and field research. Drawing conclusions from the study results was carried out by providing conclusions on data analysis which included searching for meaning and providing explanations from the data that had been obtained. The results of this study indicate; first, efforts to overcome violent crimes by increasing the effectiveness of the Extralegal system or informal system and preventive efforts including patrols, socialization, and streamlining the role of the environmental security system as well as providing training in the field of IT and repressive mapping, recording, and monitoring the network against the perpetrators/prisoners who have been arrested \& sentenced to the second, the factors that encourage perpetrators of violent criminal acts are economic factors, education, negligence of the victim, the environment and the weakness of repressive measures. An interagency Coordinating Minister and a Government Committee are formed, chaired by the Minister of Home Affairs. Policies at the Polres, such as the Serang City Police, carry out firm and measurable action in arrests; in Karawang, they have the Life360 application and carry out KRYD (improved routine activities).

\section{Introduction}

The State of Indonesia is a state based on the law as regulated in Article 1 Paragraph (3) of the 1945 Constitution of the Republic of Indonesia. Indonesia as a state of law makes law itself an ideology to create order, security, justice, and welfare for every citizen (Kansil, Rumagit, Ngangi, \& Tangkere, 2015).
All aspects of life in this country are regulated based on the rule of law, all individual behavior is regulated by law, both the law that applies in an area and the law that applies throughout Indonesia. The law must always be enforced to achieve the ideals and the purpose of the State of Indonesia which is also stated in the opening of the fourth 
paragraph of the 1945 Constitution, namely to form a government of the State of Indonesia that protects the entire Indonesian nation and all of Indonesia's bloodshed and to promote public welfare, educate the nation's life and participate in carrying out the order. A world based on freedom of law eternal peace and social justice.

The government that holds the mandate from the people must regulate and run a country with full responsibility and strive to realize the welfare and happiness of its people by making policies that must be obeyed by its people. The effort is not as easy as turning the palm. Indonesia is a developing country that is carrying out development in all fields with the main objective of providing physical and spiritual prosperity and well-being as well as peaceful social life for all Indonesian people.

However, problems in the social field social life are very many, these problems are caused by several factors and social phenomena, namely all behavior that is contrary to the norms of goodness, local stability, patterns of simplicity, morals, property rights, family solidarity, living in harmony with neighbors, discipline, kindness and formal law. These factors and symptoms are called Social Pathology. In other words, Social Pathology is Crime. Social pathology contains various forms of crime or social deviation, from time to time it develops dynamically and forms new patterns, both in terms of the way it acts and the consequences it causes (Prakoso, 2016).

The problem in developing countries such as price volatility is a result of the absence of ICT use in the agriculture sector which causes market participants to lose significant revenues; when commodity prices fall, it can exacerbate societal difficulties, such as when farms use child labor to save money on labor costs. Furthermore, farmers are frequently concerned about market instability, so they choose to either decline or reduce their market involvement (Nugroho, 2021). Moreover, problems such as crime can disrupt the stability of a community group, can also cause disturbances and threats to national stability and security. Deviations can occur in relationships between individuals and other individuals, one group with other community groups, or between communities and other communities. One example is the problem of behavior that is contrary to the law such as crime. Crime is a human problem and a social phenomenon because it can occur anywhere and anytime in social life.

In addition, anothe crime such as kidnapping is relatively common in developing countries, and unfortunately, kidnapping for ransom has become a global industry in those countries, with recorded incidents numbering in the tens of thousands each year. The negative impact of kidnapping ranges from psychological and physical effects to severe economic consequences (Okafor \& Ede, 2021). Furthermore, In Malaysia there are correlations between types of street crime, cost of living, income disparity, GDP per capita, population, and unemployment rate in Malaysia. In summary, two key street crime criminal incentive elements in Malaysia are the cost of living and GDP per capita (Latimaha, Bahari, \& Ismail, 2019).

One of the crimes or criminal acts that often occur in society is theft, this happens because the current state of society allows people to find shortcuts by stealing. The form of theft lately is increasingly widespread, mushrooming, even very disturbing people in people's lives from day today. Various modus operandi is carried out in the theft, ranging from mugging, beheading, using drugs, and even gang theft using firearms, which makes the victim unable to move.

Four perpetrators of violent theft (curas) who often act in Serang City, Serang Regency, and Pandeglang District were successfully arrested by the Serang City Police Criminal Investigation Unit. The four suspects are UC, 27, a resident of Cikeusik, Pandeglang Regency, MS, 20, a resident of Kramatwatu, Serang Regency, DN, 22, and $\mathrm{DE}, 21$, both residents of Cilegon City. 
"One perpetrator with the initials DE had to be paralyzed with hot lead because he fought back when caught," said Serang City Police Chief AKBP Komarudin during exposure at the City Police Headquarters, Friday (24/8/2018).

The police chief said that the violent theft was carried out by DN and DE by pointing at and threatening with a firearm after successfully confronting the victim. Both often act in quiet places in Serang City and Serang District. Finally, this motorbike confiscation took place in the Lotus Village, Kramatwatu, Serang Regency.

"DE was secured at his house in the Cilegon area and DN in the Kramatwatu area, Serang Regency. From the hands of the two officers, the officers secured one unit of a Suzuki Satria $F$ motorcycle and one vehicle registration sheet," said the Head of Police accompanied by Deputy Chief of Police Commissioner Andra Wardhana and Head of Criminal Investigation Unit AKP Richardo Hutasoit.

Furthermore, it was said that the perpetrator with the initials UC was secured at his house in the Cikeusik area, Pandeglang $(13 / 8)$. From the hands of these casual workers, the officers secured one $T$ key and eight motorcycles of various brands. "Usually he acts in Serang City, Panimbang, Pandeglang and Kragilan areas, Serang Regency," AKBP Komarudin.

While the MS perpetrator acted in the Kramatwatu area (13/8/2018), the perpetrator was successfully arrested by the community. The other perpetrator managed to escape. From the hands of MS, the officers managed to secure a Honda-type motorcycle complete with STNK and the original ignition key. "This was done by two people but one is still being pursued, we already know the identity," he said (Imam, 2018).

Nowadays various methods or modus operandi have developed, initially mostly carried out at night, now increasing to during the day, the equipment used has also developed from sharp weapons, simple transportation and communication tools are now turning into firearms, using conveyances, tools, and equipment sophisticated communication (Prakoso, 2016). Moreover, theft with violence with sharp weapons entails not only stealing other people's property, but also committing violence against the owner or family members. In most incidents of violent theft, the offenders of the use of sharp weapons can carry out their crimes anywhere (Rahmawaty, 2021). Likewise, how crimes occur in different ways from one crime to another and supported by the availability of facilities and infrastructure to commit crimes, the modus operandi of criminals leads to the advancement of science and the use of technology. as well as. How they are carried out can be grouped, such as ordinary theft, weight theft, light theft, and violent theft.

According to Adami Chazawi, the punishment for theft with increased punishment is a form of theft as formulated in Article 362 of the Criminal Code (its main form) plus other elements, both objective and subjective, which are aggravating the theft and are therefore threatened with a heavier sentence. from theft in its main form (Chazawi \& Ferdian, 2014).

There have been many policies and regulations that have been made in tackling corruption. In addition to curas prevention policies, it also requires proactive actions from various parties, both the police and the community. The collaboration of these parties will ensure the creation of a security condition that is fundamental to the achievement of progress in all sectors, which will ultimately lead to an increase in people's welfare.

The crime rate, especially for general crimes (medium) in Serang Regency and Serang City during 2011 reached 500 cases. Some of these cases have been decided, are in process, and are still under investigation. What stands out is the theft, both the theft of motorbikes, houses, and theft with violence and weight. Other crimes include drug abuse, murder, commotion, domestic violence 
(KDRT), as well as the doubling of counterfeit money," said Muhammad Mahmud, Head of Criminal Investigation Unit at the Serang District Attorney's Office. (Source: Editorial Team of the Indonesian Prosecutor's Office/Kejari Serang)

In the Criminal Code (KUHP) there are three types of theft. The three types of theft are ordinary theft, weighted theft (curate), and violent theft (curas). Of the three, curas is the most troubling to the public2 and the most dangerous, "because the "taking of other people's goods" is preceded, accompanied, or followed by violence or threats of violence against the victim with the intention of or preparing or facilitating the theft (Basitha, Wirasila, \& Widhiyaastuti, n.d.) Victims not only suffered material losses but also physical losses, some even lost their lives.

Curas is regulated in Article 365 of the Criminal Code with a maximum penalty of up to 12 years in prison. The threat of severe punishment does not seem to have stopped the robbery case, but it still keeps happening.

P.A.F. Lamintan and Jisman Samosir said that what is meant by theft with violence or weighting is an act of theft that has elements of the act of theft in its main form, and because it is added with other elements, the threat of punishment becomes aggravated (Lamintang \& Samosir, 2010).

But in reality, the order of life that has been regulated in various laws and regulations is still widely violated. Deviations in behavior or unlawful acts committed by the community are caused by various factors including the negative impact of rapid development, the flow of globalization, advances in communication and information, advances in science and technology as well as changes in the style and way of life of some people. bring about fundamental changes in people's lives.

\section{Method}

Research is a process (Soekanto, 2014), which is a series of steps carried out in a planned and systematic way to obtain problem-solving or answers to certain questions (Hakim \& Saebani, 2008).

According to Soerjono Soekanto, legal research is a scientific activity, which is based on certain methods, systematics, and thoughts, which aims to study one or several certain legal phenomena, by analyzing them (Soekanto, 2014).

The nature or specification of the research used in this research is descriptiveanalytical, which describes the applicable laws and regulations associated with legal theories and positive law enforcement practices concerning the above issues. Descriptive research is a type of research that provides a description or description of a situation as clearly as possible on the object under study (Soekanto, 2014). Through this descriptive method, this research is expected to be able to provide a comprehensive and systematic picture, to then carry out an analysis of the data obtained and in the end get a problemsolving.

It is said to be descriptive because this research is expected to be able to provide a detailed, systematic, and comprehensive picture of all matters relating to the implementation of laws and regulations in Indonesia which regulate violent crimes and vice versa, the obligation of the State as the holder of the main obligation to protect the community by finding ways to overcome them. The approach used in this study is a normative juridical approach. A juridical approach is an approach in terms of laws and regulations and legal norms by the existing problems, while the normative approach is to emphasize research-based on something factual written which aims to gain knowledge of laws and regulations concerning research problems (Soemitro, 1990).

This study will examine the application of the legal principles of criminal policy issues in the act of theft with violence to prevent criminal acts from occurring through policies taken by stakeholders manifested physically through law enforcement in imposing 
sanctions for perpetrators of criminal acts of theft and followed by all elements of society starting from the environment in which we live to create a sense of security in activities both at home and outside the home.

The research was conducted with a normative juridical approach that examines the application of laws and regulations in Indonesia that regulates the problem of theft with violence against reports on various obstacles that have been encountered in its implementation by the appointed agency.

In full, the types of normative legal research include:

1. Research on legal principles,

2. Research on legal systems,

3. Research on the level of vertical and horizontal synchronization,

4. Comparative law research,

5. Legal history research,

6. Research positive legal inventories and,

7. Research to find the in-concreto law, research will be carried out to support the research results (Widjayani, 2007).

Researchers also realize that research that only relies on secondary data does not support objective and acceptable conclusions according to scientific principles or principles that can be accounted for academically. Thus the researchers tried to find data from field research to complete the existing library data. For this reason, the research carried out includes two stages, namely library research and field research.

This writing uses legal materials, both primary legal materials, and secondary legal materials, and tertiary legal materials.

Based on the type and form, the data needed in this study is secondary data obtained through a literature study.

Secondary data is data obtained from a second source. However, to complement or support secondary data analysis.

The secondary data used in this thesis can be divided into several types of legal materials, in this case, primary legal materials, and secondary legal materials, as follows:
1. Primary legal materials It can be seen from the binding force covering the products of legislative institutions. In this case, the materials in question are legal materials which include those contained in statutory regulations. In this case, the material in question is the book of the Criminal Code (KUHP) and Court Decisions.

2. The materials used are materials that provide information or matters relating to the content of primary sources and their implementation, for example, the Draft Criminal Code (KUHP), Research Reports, scientific articles, books, papers of various scientific discoveries, theses, theses, and dissertations.

3. Tertiary legal materials, in the form of materials that support primary and secondary legal materials, such as dictionaries, language dictionaries, articles in newspapers, magazines, and the internet.

Field research is also carried out to obtain primary data as supporting data, primary data collection is carried out by interview by first determining the parties who are used as sources of information based on their authority, knowledge, experience, and understanding and expertise in the field of criminal law policy. . The field research includes the Serang City Police-Banten Police and Karawang-West Java Police.

Secondary data were analyzed using a normative qualitative analysis method, by interpreting, correlating, and comparing legal materials and comparing legal constructions of several legal concepts relevant to this study.

\section{Results And Discussion}

Action Countermeasures Criminal theft with violence

A. Efforts to overcome criminal acts in Indonesia

To achieve peace and prosperity many ways have been done, such as: 
Identify various social aspects that are suspected as conducive factors causing crime.

1) Poverty, unemployment, illiteracy, lack of proper housing and unsuitable education and training systems;

2) The increasing number of people who do not have prospects (hope) due to the process of social integration and the arena of worsening social inequalities;

3) Loosening of social and family ties;

4) Circumstances or conditions that make it difficult for people immigrating to other cities or countries;

5) The destruction or destruction of indigenous cultural identities, which together with the existence of racism and discrimination causes weaknesses in the social, welfare, and work environment;

6) The decline or decline in the quality of the urban environment encourages an increase in crime and inadequate services for neighboring neighborhood facilities;

7) Difficulties for a person in modern society to integrate properly within his community, in his family, work, or school environment;

8) Abuse of alcohol, drugs, and others whose use is also expanded due to the factors mentioned above;

9) The spread of organized crime activity, particularly drug trafficking and the containment of stolen goods;

10) Encouragements (especially by the mass media) regarding ideas and attitudes that lead to acts of violence, inequality (rights), or intolerant attitudes.

B. Factors that encourage the crime of theft with violence and obstacles in efforts to combat the crime of theft in Indonesia

1. Economic factors

2. Educational factor

3. The factor of negligence/negligence of the victim himself
C. Many factors that encourage perpetrators of criminal acts of theft with violence are usually external and internal, namely:

1. Internal factors

a. Educational Factor

The education factor is one of the factors driving a person to commit a crime of theft. This is due to their low level of knowledge on things such as rules in the way of living in society.

b. Individual Factor

Someone whose behavior is good will result in that person getting an award from the community, but on the contrary, if someone behaves badly then that person will cause chaos in society.

2. External Factors

The external factor of a person committing a crime is focused on the perceived condition of the community so that it makes him feel hopeless and take quick steps. This factor becomes very influential when conditions become more difficult and decisions are felt by many parties.

D. Criminal Policy for Perpetrators and Victims of Violent Crimes in Obtaining Justice.

1. Policy or Rules for the Crime of Theft With Violence and Weighting

The policy or juridical basis that regulates the crime of theft is the Criminal Code (KUHP) which in detail describes the crime of theft in Chapter XXII concerning theft. The crime is regulated in Article 365 of the Criminal Code which reads:

a. By a maximum imprisonment of nine years, theft which is preceded, accompanied or followed by violence or threats of violence, against a person with the intent to prepare or facilitate the theft, or in the case of being caught redhanded, to enable the escape of 
oneself or another participant, or to maintain control. stolen goods.

b. Threatened with a maximum imprisonment of twelve years.

c. If the act results in death, it is punishable by a maximum imprisonment of fifteen years.

d. Threatened with capital punishment or imprisonment for life or a certain period of not more than twenty years, if the act results in serious injury or death and is committed by two or more people in partnership, accompanied by one of the things described in no. 1 and 3.

To fulfill the right mental attitude for the perpetrators of the crime of theft, a good legal mechanism is needed in all aspects of handling by carrying out the values contained in the legal system from the basic level to the punishment of the perpetrators in the suspect process were in institutions:

a. advocate

Article 56 paragraph (1) of the Criminal Procedure Code If a suspect or defendant is suspected or charged with committing a criminal act which is punishable by the death penalty or a sentence of fifteen years or more or for those who cannot afford it who are threatened with a sentence of five years or more who do not have legal counsel themselves, the officials concerned at all levels of examination in the judicial process are obliged to appoint legal counsel for them.

In the sense that since the examination stage of the investigation, a suspect has the right to be accompanied by a legal advisor. A legal advisor is to provide legal assistance to his clients in court and outside the court such as accompanying, representing, defending. The right of the perpetrator of the crime of theft to be optimized in obtaining legal assistance in the process of investigating criminal cases is a right that must be possessed by the suspect in obtaining legal assistance, in this case, is a legal adviser/advocate since the beginning of the examination of the case. In the investigation process in the police, the role of a legal advisor is as a companion so that the rights of the suspect/client are not violated by the police investigator, one of the rights granted to the accused in the process of resolving criminal cases is the right to obtain legal assistance, in addition to several rights. other things such as getting an examination, the right to be notified of his guilt, the right to have a family visit, and others, because after all a suspect/client who is being investigated has the same rights before the law as other people.

In the sense that since the examination stage of the investigation, a suspect has the right to be accompanied by a legal advisor. A legal advisor is to provide legal assistance to his clients in court and outside the court such as accompanying, representing, defending. The right of the perpetrator of the crime of theft to be optimized in obtaining legal assistance in the process of investigating criminal cases is a right that must be possessed by the suspect in obtaining legal assistance, in this case, is a legal adviser/advocate since the beginning of the examination of the case. In the investigation process in the police, the role of a legal advisor is as a companion so that the rights of the suspect/client are not 
violated by the police investigator, one of the rights granted to the accused in the process of resolving criminal cases is the right to obtain legal assistance, in addition to several rights. other things such as getting an examination, the right to be notified of his guilt, the right to have a family visit, and others, because after all a suspect/client who is being investigated has the same rights before the law as other people.

b. Police

The term policy is as an organ and as a function (Sadjijono, 2006). An organ, which is a government institution that is organized and structured in a state organization. Meanwhile, as a function, namely the duties and authorities and responsibilities of institutions with the power of law to carry out their functions, including maintaining public security and order, law enforcement, protectors, protectors, and public servants.

c. attorney

The law enforcement process carried out will focus on punishment to the perpetrators while still accommodating the rights and interests of the victims. The public prosecutor, in this case, positions himself as a victim, so that he can understand and understand what interests the victim must obtain through the law enforcement process. Prosecutors will ensure that the law enforcement process that takes place is not only fair for the perpetrators of the crime but also for the victims who are harmed by the crime.

Related to the legal interests of victims of crime in the criminal justice system, a prosecutor's role is needed in prioritizing these interests. This has been stated in:

1) Attorney General's Instruction Letter No. B-63/E/2/1994 concerning Protection of Victims of Crime. In the instruction, it is stated that the loss suffered by the other party is included in the loss of the victim. This refers to Article 98 of the Criminal Procedure Code. The Instruction Letter contains the following:

a. To take advantage of Article 98 of the Criminal Procedure Code in protecting the interests of victims of crime, by trying to combine claims for compensation filed by victims of crime with their criminal cases.

b. The victim of a crime or his family is given information from an early age regarding his right to file a claim for compensation against the perpetrator of the crime.

c. Approaching the judges to obtain the same perception.

d. Evidence that is a means of livelihood for a crime victim or his family, such as a vehicle and so on can be considered for borrowing by the victim or his family.

e. Other efforts are taken which in principle can help crime victims which are expected to have a positive impact on increasing community participation (especially crime victims) in law enforcement, for example being encouraged to immediately report any criminal acts that occur, being willing to be witnesses or participating in efforts to prevent crime. crime occurs. 
2) The instructions above are then strengthened with instructions Number: B-187/E/5/3/95 regarding Protection of Victims of Crime. The instructions contain the following:

a. So that since the proprosecution stage the Public Prosecutor has notified the victims of the crime, both members of the community and the State c.q. Relevant agencies/institutions

regarding their rights to file claims for material damages suffered before the criminal charges are read out by Article 98 of the Criminal Procedure Code. While other losses can be filed through a civil process as described in Chapter IV of the Decree of the Minister of Justice of the Republic of Indonesia Number: M.01/PW.07.03 of 1982

b. If the defendant deserves to be prosecuted with a suspended sentence, the provisions of Article $14 \mathrm{c}$ of the Criminal Code must be applied by including the obligation to pay compensation to the victim of a crime as a special condition.

c. If a non-probationary sentence is demanded, the Public Prosecutor is expected to approach the Judge for the possibility of developing jurisprudence by imposing additional penalties on the defendant paying compensation to the crime victim.

d. Seek other measures that can assist in recovering the losses suffered by victims of crime, both material and immaterial, by involving social agencies, both established on the initiative of the community and at the encouragement of the government.

\section{Conclusion}

From the results of the discussion of the research problems in this dissertation, it can be concluded that:

An integral crime prevention effort in society with all its potential must be viewed as a criminal policy. All community organizations must be considered anticriminogenic, and public relations are the basis for crime prevention programs. Therefore, it is necessary to foster and improve the effectiveness of the "extra-legal system" or "informal system" that exists in the community in crime prevention efforts.

Various factors, including economic factors, cause deviations in behavior or unlawful acts committed by the community; on average, all the perpetrators who have been arrested have lower-class economics and do not have permanent jobs. The average elementary/junior high school graduate's education factor has a mindset that is easily influenced to take actions that harm others. The factor of negligence/negligence of the victim makes the perpetrator who initially had no intention but saw the victim in a state of carelessness. The perpetrator just thought of cheating. Weak factors of repressive actions or law enforcement from interested officials, such as getting punishments that are not commensurate with the actions taken, so that the purpose of the law to provide a deterrent effect are not achieved, even when someone is released from the penitentiary, they tend to commit criminal acts again.

Crime prevention must be pursued through an integral approach/policy. The policy of overcoming it must involve agencies/ministries integrally and based on our view that crime is a "social pathology" 
and the causes are pretty numerous (covering various aspects). Then the coordinating minister for inter-agency and government commission for crime prevention was then formed, abbreviated as "government committee ." this commission is chaired by the minister of home affairs, which consists of representatives from the ministry of home affairs, ministry of finance, ministry of health, ministry of human resources, ministry of development of disadvantaged regions and transmigration, ministry of youth and sports, attorney general's office, national police, Indonesia police watch (IPW), and each makes a social prevention program, to form an integral prevention system. its main objective is to limit opportunities to commit crimes.

\section{Suggestion}

Many efforts can be made in tackling violent theft, such as:

To increase the effectiveness of the "extra-legal system" or "informal system" it is better to cooperate with social and religious organizations, educational institutions, and volunteer organizations in the community.

In preventive efforts, the police further enhance their role, include community participation. and use the moralistic method by fostering mental and spiritual practices carried out by scholars, educators, and abolitionistic methods using conceptual countermeasures that must be planned based on criminological research and explore the causes because of various interrelated factors.

Repressive efforts, in addition to carrying out training and providing special police tools, also require good cooperation from the criminal justice system which has 5 (five) subsystems of justice, prosecutors, police, correctional facilities, lawyers, which are a whole that is strung together and functionally related. in its implementation, it is also carried out by the method of treatment (treatment) and punishment (punishment).

\section{References}

Basitha, Rinanda, Wirasila, A. A. Ngurah, \& Widhiyaastuti, I. Gusti Agung Ayu Dike. (n.d.). Peranan Saksi Mahkota (Kroongetuide) Dalam Persidangan Tindak Pidana Pencurian Dengan Kekerasan Sebagai Alat Bukti (Studi Di Pengadilan Negeri Denpasar).

Chazawi, Adami, \& Ferdian, Ardi. (2014). Tindak pidana pemalsuan: tindak pidana menyerang kepentingan hukum terhadap kepercayaan masyarakat mengenai kebenaran isi tulisan dan berita yang disampaikan. PT. RajaGrafindo Persada.

Hakim, Atang Abdul, \& Saebani, Beni Ahmad. (2008). Filsafat Umum dari metologi sampai Teofilosofi.

Imam, N. (2018, Agustus 24). Retrieved December 2021, from Media Banten: https://mediabanten.com/polres-serangkota-catch-4-perlaku-pencurian-denganviolence

Kansil, Chichi S. T., Rumagit, Grace A. J., Ngangi, Charles R., \& Tangkere, Ellen G. (2015). Tingkat Kepuasan Konsumen "Sop Buah Ica" di Boulevard Manado. $\operatorname{cocos}, 6(2)$.

Lamintang, P. A. F., \& Samosir, C. Djisman. (2010). Delik-delik khusus kejahatan yang ditujukan terhadap hak milik dan lain-lain hak yang timbul dari hak milik. Nuansa Aulia.

Latimaha, R., Bahari, Z., \& Ismail, N. A. (2019). Examining the linkages between street crime and selected state economic variables in Malaysia: A panel data analysis. J. Ekon. Malays, 53, 5972.

Nugroho, A. D. (2021). Agricultural market information in developing countries: A literature review. Agricultural Economics, 67(11), 468-477. Google Scholar

Okafor, G., \& Ede, O. (2021). Kidnapping rate and capital flight: Empirical evidence from developing countries. International 
Journal of Finance \& Economics. Google Scholar

Prakoso, Abintoro. (2016). Sistem, Metode, Aliran dan Prosedur dalam Menemukan Hukum

Rahmawaty, S. (2021). Tinjauan kriminologis pencurian dengan kekerasan yang menggunakan senjata tajam di Wilayah Hukum Polda Jawa Barat. UIN Sunan Gunung Djati Bandung. Google Scholar

Sadjijono. (2006). Hukum kepolisian: perspektif kedudukan dan hubungannya dalam hukum administrasi. Laksbang
Presindo

Soekanto, Soerjono. (2014). Sosiologi suatu pengantar. Jakarta : Rajawali Pers

Soemitro, Ronny Hanitijo. (1990). ukum Dan Perkembangan IImu Pengetahuan Dan Teknologi Di Dalam Masyarakat. Documentation. Diponegoro University Press, Semarang.

Widjayani, S. S. (2007). Metode Penelitian Hukum Normatif, Bahan Kuliah. Bandung: Program Pasca Sarjana Unpad.

\section{Copyright holder:}

Imam Ramadhani (2022)

First publication right:

Journal of Social Science

This article is licensed under:

(c) (i) (?) 